Table 1-Results of survey on eating habits of random selection of doctors and patients conducted during beef crisis. Figures are numbers (percentages)

\begin{tabular}{|c|c|c|c|c|c|}
\hline & $\begin{array}{l}\text { Had stopped } \\
\text { eating beef }\end{array}$ & $\begin{array}{l}\text { Had stopped } \\
\text { eating beef } \\
\text { products }\end{array}$ & $\begin{array}{l}\text { Allowed } \\
\text { children to } \\
\text { eat beef }\end{array}$ & $\begin{array}{l}\text { Allowed } \\
\text { children to } \\
\text { eat beef } \\
\text { products }\end{array}$ & Significance \\
\hline Doctors $(n=43$ ) & $8(19)$ & $20(47)$ & $33(77)$ & $19(44)$ & $\chi^{2}=7.0, P<0.01$ \\
\hline Patients ( $n=44$ ) & $20(45)$ & $32(73)$ & $11(25)$ & $4(9)$ & $\chi^{2}=6.2, P<0.05$ \\
\hline \multicolumn{6}{|c|}{ Patients by occupational class: } \\
\hline II, IIIN, IIIM (n=31) & $12(39)$ & $21(68)$ & $11(35)$ & $4(13)$ & $\chi^{2}=23.3, P<0.001$ \\
\hline IV, $V(n=13)$ & $6(46)$ & $10(77)$ & 0 & 0 & $\chi^{2}=13.7, P<0.001$ \\
\hline \multicolumn{6}{|l|}{ Sex: } \\
\hline Male $(n=48)$ & $5(10)$ & $21(44)$ & $31(65)$ & $18(38)$ & \\
\hline Female $(n=39)$ & $23(59)$ & $31(79)$ & $13(33)$ & $5(13)$ & \\
\hline
\end{tabular}

43 doctors and 44 patients to determine whether their beef eating habits differed during this crisis and what influence, if any, sex and socioeconomic status might have had.

Table 1 shows my findings. Patients were more likely to have stopped eating beef than doctors and to have stopped eating beef products. They were more likely not to allow young children to eat beef $(33(75 \%))$ and beef products $(40$ $(91 \%))$ than were doctors $(10(23 \%)$ and 24 (56\%) respectively). When patients' responses were analysed by occupational class those in classes IV and $\mathrm{V}$ were more likely to have stopped eating beef and beef products than their counterparts in classes II and III. None of those in classes IV or $\mathrm{V}$ would allow young children to eat beef or beef products. When both patients and doctors were analysed by sex women were more likely than men to have stopped eating beef and beef products and less likely than men to allow children to eat these products.

It is not surprising that doctors, with their medical knowledge, have been less worried about bovine spongiform encephalopathy and whether to eat beef than have patients. If, however, the public realised that their own doctors were continuing to eat beef then they might be less concerned. My findings show that socioeconomic status influences eating habits; this possibly reflects educational background (and thus the ability to separate facts and risks from the hype) and sources of information (for example, broadsheet rather than tabloid newspapers)

An important issue is the power of the media to influence diet. If people in lower socioeconomic groups continue to eat less red meat, beefburgers, sausages, etc and to preven their children from eating these then a fall in the incidence of ischaemic heart disease may result-an unexpected benefit of the saga.

HELEN COHEN

Llandough Hospital,

House officer in general medicine

Penarth,

Cardiff CF64 2XX

1 Lacey RW. Creutzfeldt-Jakob disease and bovine spongiform encephalopathy. BMf 1996;312:180-1. (20 January.)

2 Almond JW, Brown P, Gore SM, Hofman A, Wientiens DPWM, Ridley RM, et al. Creutzfeldt-Jakob disease and bovine spongiform encephalopathy: any connection? $B M 9$ 1995;311:1415-21. (25 November.)

3 Brown P. Bovine spongiform encephalopathy and Creutzfeld tJakob disease. $B M$ I 1996;312:790-1. (30 March.)

4 Delamothe T. Meltdown: the media and mad cows. BMF 1996;312:854-5. (30 March.)

\section{Rehabilitation after brain injury}

Author's experience is not unique...

EdrToR,-It is curious: A N Bamji's experience of trying to remedy deficiencies in the provision of rehabilitation for patients with brain injury is being repeated all over Britain. ${ }^{1}$ Why is this?

There is no lack of epidemiological evidence of the dire effects of head injury on young men (it affects mainly males) and their families for up to 50 years. $^{2}$ As Greenwood stated recently ${ }^{3}$ in a review of a book detailing many models of service providers, ${ }^{4}$ rehabilitation of patients with brain injury is effective. Authoritative statements about the services required have been available for many years-for example, from the British Society of Rehabilitation Medicine (previously the Medical Disability Society). ${ }^{5}$ The Department of Health has set up the brain injury initiative, in which 12 centres will produce data on the effectiveness of their services.

Yet it seems that purchasers and, presumably, their public health consultants fail to see these patients' needs as being of sufficient priority for them to work with providers to provide or enlarge services. Innovation here seems difficult to achieve. The financial risks attached to such new developments cannot be great, since the cost of sending a single untreated patient with a severe injury into the private sector for some two years' treatment is of the order of $£ 100000$. Who holds the key to better things for the majority of brain injured patients?

M A CHAMBERLAIN Professor of rehabilitation medicine Rheumatology and Rehabilitation Research Unit, University of Leeds,

Leeds LS2 9NZ

1 Bamii AN. Brain injury rehabilitation: jaw jaw not war war BMf 1996;312:916-7. (6 April.)

2 Tennant $A$. The epidemiology of head injury. In: Chamberlain MA, Neumann V, Tennant A, eds. Traumatic brain injury rehabilitation: services, treatments and outcomes. London Chapman and Hall, 1995:12-24

3 Greenwood RJ. Traumatic brain injury rehabilitation: services, treatments and outcomes [book review]. BMF 1996;312:192. (20 January.)

4 Chamberlain MA, Neumann V, Tennant A, eds. Traumatic brain injury rehabilitation: Services, Treatments and Outcomes. London: Chapman and Hall, 1995.

5 Medical Disability Society. The management of traumatic brain injury. London: Development Trust for the Young Disabled, 1988.

\section{...or new}

EDITOR,-It may be some comfort for A N Bamji to learn that the struggle to establish rehabilitation services for patients with brain injury in the face of inertia and obfuscation is not a new phenomenon. ${ }^{1}$ The reference to war in the title of Bamji's article is particularly pertinent, for during the second world war the foundations for what is required were laid.

Early in the 1940s the Medical Research Council established a committee to advise on the promotion of research into the effects and treatment of war injuries to the brain. ${ }^{2}$ Rehabilitation was emphasised along with the concepts of the team approach, the importance of clinical psychology, and the goal of resettlement in the community. Although the committee was set up in anticipation of the need to treat battlefield casualties, most cases were the result of road traffic accidents and many patients were civilians. Two units of a regional nature existed in
Scotland, and in his annual report of 1945 the medical officer of health for the City of Edinburgh put a strong case for their continuation in peacetime. ${ }^{3}$ His advice went unheeded, and the rehabilitation services were allowed to wither. The idea was resurrected in the Mair report of $1972 .{ }^{4}$ Ten years later an unusual armistice occurred between clinicians and academics from the rival cities of Edinburgh and Glasgow in an attempt to realise this recommendation. This led to a further decade of constructive, convivial, but fruitless dialogue.

Eventually, in $1991, £ 500000$ was set aside over three years to provide for the entire population of Scotland. Three small units were approved for the rehabilitation of patients with brain injury; they had no direct funding but depended on the vagaries of the medical market. The unit at Astley Ainslie Hospital is fortunate in having the support of Lothian Health and other purchasers, but demand outstrips resources and many patients do not get adequate medical rehabilitation, especially those living at a distance; access for families and carers is integral to successful resettlement. It is salutary to reflect that the one time there was the prospect of substantial development money was in anticipation of casualties in the Gulf war. Fortunately, that conflict did not result in many such casualties. The casualties on our roads create more disabled people than many a war, but despite lip service being paid to rehabilitation no priority is given to it. So it is a case of both war and jaw.

BRIAN PENTLAND Consultant neurologist

Astley Ainslie Hospital,

Edinburgh EH9 2HI

Bamji AN. Brain injury rehabilitation: jaw jaw not war war. BMF 1996;312:916-7. (6 April.)

Green FHK, Covell G, eds. Medical research. London: HMSO, 1953:79-82

3 Pentland B, Boake C, McKinlay WW. Scottish head injury rehabilitation: an historical account. Scott Med $f$ 1989;34:411-2.

4 Scottish Home and Health Department Medical rehabilitation: the pattern for the future. Edinburgh: HMSO, 1972.

\section{Laboratory tests for Helicobacter pylori should be more widely available}

EDITOR,-The presence of Helicobacter pylori is an increasingly important consideration in the management of patients with dyspepsia. Recent strategies for managing dyspepsia in primary care $^{12}$ and for the use of gastroscopy services have incorporated the patient's $H$ pylori status as a specific decision point.

For general practitioners to be able to implement these new management strategies effectively they require access to diagnostic test for $H$ pylori, both to identify those patients who are infected and to confirm the success of eradication treatment. The commonly available non-invasive tests are carbon-13 and carbon-14 urea breath tests and laboratory based microtitre serum antibody assays.

The Primary Care Society for Gastroenterology conducted a postal questionnaire survey of all general pathology laboratory services in Britain in July 1995, seeking details of the availability of non-invasive tests and whom they were offered to. Pathology services in paediatric, maternity, and other specialist hospitals were excluded from the study. A total of 133 laboratories were identified, of which 103 (77\%) responded (table 1). Sixty seven of the laboratories provided serum antibody tests. Twenty one provided urea breath tests, although five others stated that the gastroenterology department in their hospital did these. Only 65 laboratories offered a non-invasive test to general practitioners. Twenty eight laboratories offered no tests at 